\title{
SISTEM INFORMASI KEBUTUHAN BAHAN PEMBANGUNAN RUMAH BERBASIS WEBSITE (STUDI KASUS: PT. TANIYA MULTI PROPERTI)
}

\author{
David Everaldo, Sentot Achmadi, Yosep Agus Pranoto \\ Program Studi Teknik Informatika S1, Fakultas Teknologi Industri \\ Institut Teknologi Nasional Malang, Jalan Raya Karanglo km 2 Malang, Indonesia \\ Davideveraldo24@gmail.com
}

\begin{abstract}
ABSTRAK
Persaingan dagang penjualan tanah kavling yang ada di Kabupaten malang sangat ketat, hal ini dikarenakan banyaknya PT yang bersaing memberikan fasilitas yang baik pada produk yang dipasarkan. Perusahaan yang memiliki sistem informasi pada penjualan produknya akan memaksimalkan jumah penjualannya. PT. Taniya Multi Properti tidak memiliki sistem informasi dalam penjualan produknya. Sehingga user tidak mengetahui informasi produk yang disediakan oleh perusahaan dan kemudian akan menimbulkan penurunan penjualan dibandingkan perusahaan pesaing lainnya. Berdasarkan permasalahan tersebut, pemanfaatan sistem informasi akan dioptimalkan untuk memberikan informasi penjualan produk yang disediakan oleh PT. Taniya Multi Properti serta merencanakan penyediaan bahan bangunan untuk membangun rumah setelah mengetahui informasi hasil prediksi bahan bangunan dari data lampau. Dengan adanya sistem informasi sebagai sarana pemasaran dan promosi, maka nformasi penjualan produk bisa mencakup masyarakat yang lebih luas. Dengan adanya sistem informasi juga dapat mempermudah penyebaran informasi kepada calon pembeli mengenai layanan yang disediakan perusahaan serta fitur forecast didalamnya dapat mempermudah meramalkan hasil penjualan dan jumlah bahan yang perlu dipersiapkan untuk membangun produk yang akan dipasarkan. Berdasarkan hasil pengujian yang ada dapat disimpulkan bahwa pengimplementasian metode pada website dengan pengujian perhitungan menunjukkan hasil uji perhitungan metode menggunakan data penjualan Rumah PT. Taniya Multi Properti tahun 2019 sebanyak 12 unit. Namun pada data aktual memperoleh data sebanyak 4 unit. Oleh karena itu di buat perhitungan nilai error dengan menggunakan metode MAPE dan memperoleh hasil persentase error sebesar 25\% yang berarti wajar. Dan hasil uji keakurasian untuk penjualan rumah dengan menggunakan data penjualan rumah pada periode selanjutnya (2021) menghasilkan data forecast sebesar 0 unit, sedangkan data aktual penjualan 2021 sebesar 3 unit. Oleh karena itu di buat perhitungan nilai error dengan menggunakan metode MAPE dan memperoleh hasil persentase error sebesar 16,667\% yang berarti baik.
\end{abstract}

Kata Kunci: Sistem informasi, Forecasting, Sistem Informasi Penjualan.

\section{PENDAHULUAN}

Sistem informasi adalah sebuah bidang yang menyatukan sebuah ilmu pengetahuan teknologi dan manajemen serta bisnis, serta sering digunakan untuk pemasaran produk suatu perusahaan baik pengiklanan maupun marketplace banyak perusahaan yang menggunakan ilmu pengetahuan teknologi dalam pemasaran produknya.

PT. Taniya Multi Properti adalah sebuah perusahaan yang bergerak dibidang industri penjualan tanah kavling serta penjualan rumah. Bagian tanah yang sudah dipetak-petak dengan ukuran tertentu yang akan dijadikan bangunan atau tempat tinggal, terdapat bermacam-macam bentuk tanah kavling dan tipe rumah. Masalah yang dihadapi PT Taniya Multi Properti adalah tidak adanya sistem informasi untuk memasarkan produk serta perencanaan proyek seperti ketersediaan bahan bangunan sebagai perencanaan pembangunan masih belum terkoordinir secara efisien.
Persaingan dagang penjualan tanah kavling yang ada di Kabupaten malang sangat ketat, hal ini dikarenakan banyaknya PT yang bersaing memberikan fasilitas yang baik pada produk yang dipasarkan. Perusahaan yang memiliki sistem informasi pada penjualan produknya akan memaksimalkan jumah penjualannya. PT. Taniya Multi Properti tidak memiliki sistem informasi dalam penjualan produknya. Sehingga user tidak mengetahui informasi produk yang disediakan oleh perusahaan dan kemudian akan menimbulkan penurunan penjualan dibandingkan perusahaan pesaing lainnya.

Berdasarkan permasalahan diatas, pemanfaatan sistem informasi akan dioptimalkan untuk memberikan informasi penjualan produk yang disediakan oleh PT. Taniya Multi Properti serta merencanakan penyediaan bahan bangunan untuk membangun rumah setelah mengetahui informasi hasil prediksi bahan bangunan dari data lampau. 


\section{TINJAUAN PUSTAKA}

\subsection{Penelitian Terdahulu}

Penelitian terkait sistem informasi telah banyak dilakukan ole berbagai peneliti, salah satunya seperti Bangun Unedo Putra Manurung (2015) pada penelitiannya yang berjudul "Implementasi Least Square Dalam Untuk Prediksi Penjualan Sepeda Motor PT Graha Auto Pratama", dimana penelitian ini bertujuan untuk mendapatkan prediksi penjualan motor berdasarkan data penjualan motor pada PT tersebut.

Penelitian berikutnya yaitu oleh Ivo Firstiano dkk (2020) dengan karya ilmiahnya yaitu "Forecasting Omzet Menggunakan Metode Least square", penelitian tersebut bermaksud untuk memprediksi omzet penjualan produk pada coffeshop Kopinesia pada tahun yang akan datang.

Adapun Penelitian Danar Putra Pamungkas (2016) pada penelitiannya yang berjudul "Implementasi Metode Least Square Untuk Prediksi Penjualan Tahu Pong”, penelitian tersebut untuk membantu meramalkan jumlah penjualan tahu pong pada periode selanjutnya dengan menggunakan metode least square.

Penelitian yang lainnya yaitu Josef Bernadi (2013) karya ilmiah yang ditulis dengan judul "Aplikasi Sistem Informasi Penjualan Berbasis Web Pada Toko Velg YQ” Membuat sebuah sistem informasi penjualan berbasis website dengan tujuan untuk memasarkan produk yang ditawarkan oleh toko velg YQ.

\subsection{PT. Taniya Multi Properti}

PT. Taniya Multi Properti adalah sebuah perusahaan yang bergerak dibidang industri penjualan tanah kavling serta penjualan rumah yang terletak di Desa Mboro Kecamatan Kepanjen Kabupaten Malang. PT. Taniya Multi Properti berdiri sejak september 2018 oleh Hongki Frandana. PT. Taniya Multi Properti menjual berbagai macam tipe rumah dan tanah dengan rincian bervariasi, jam kerja kantor pemasaran setiap hari senin sampai sabtu pada pukul $08.00-$ 16.00 WIB.

\subsection{Website}

Website merupakan fasilitas internet yang menghubungkan dokumen dalam lingkup lokal maupun jarak jauh. Dokumen pada website disebut dengan web page dan link dalam website memungkinkan pengguna bisa berpindah dari satu page ke page lain (hyper text), baik diantara page yang disimpan dalam server yang sama maupun server diseluruh dunia. Pages diakses dan dibaca melalui browser seperti Netscape Navigator atau Internet Exploler berbagai aplikasi browser lainnya. (Hakim Lukmanul, 2004).

Terdapat 3 unsur yang sangat vital pada website. Tanpa adanya semua unsur ini, website anda tidak akan pernah ditemukan dan diakses oleh pengguna di internet. Ketiga unsur yang dimaksud adalah:

1. Domain. Jika website diibaratkan sebagai produk, maka domain adalah merk. Penggunaan domain yang menarik akan membuat orang tertarik untuk memasuki suatu website. Dengan pemilihan nama domain yang unik juga membuat orang mudah mengingatnya untuk nantinya dikunjungi kembali.

2. Hosting. Tidak kalah pentingnya dengan domain, hosting memiliki peran untuk menyimpan semua database (script, gambar, video, teks dan lain sebagainya) yang diperlukan untuk membentuk suatu website.

3. Konten. Tanpa adanya konten pada website, maka website bisa dikatakan tidak memiliki tujuan yang jelas. Konten pada website dapat berupa teks, gambar atau video. Jika dilihat dari konten yang disuguhkan, terdapat beberapa macam website. Misalnya saja, sosial media, website berita, website jual beli atau website yang berisi konten yang berdasarkan minat, bakat serta hobi.

\subsection{Php}

Karya ilmiah yang di laksanakan oleh Rasjid, Fajar Efendi (2014). Menyimpulkan bahwa PHP adalah singkatan dari Hypertext Prepocessor, yaitu bahasa pemrograman yang digunakan secara luas untuk penanganan pembuatan dan pengembangan sebuah situs website dan bisa digunakan bersamaan dengan HTML. PHP diciptakan oleh Rasmus Lerdorf pertama kali tahun 1994. Pada awalnya PHP adalah singkatan dari Personal Home Page Tools.

PHP juga banyak diaplikasikan untuk pembuatan program-program seperti sistem informasi klinik, rumah sakit, akademik, keuangan, manajemen aset, manajemen bengkel dan lain-lain. Dapat dikatakan bahwa program aplikasi yang dulunya hanya dapat dikerjakan untuk desktop aplikasi, PHP sudah dapat mengerjakannya.

\subsection{Flowchart}

Menurut Wibawanto (2017:20) "Flowchart adalah suatu bagan dengan simbol-simbol tertentu yang menggambarkan urutan proses secara mendetail dan hubungan antara suatu proses (intruksi) dengan proses lainnya dalam suatu program". Diagram alur dapat menunjukan secara jelas, arus pengendalian suatu algoritma yakni bagaimana melaksanakan suatu rangkaian kegiatan secara logis dan sistematis.

\subsection{Data Flow Diagram}

Menurut Sukamto dan Shalahuddin (2014:288), "Data Flow Diagram atau dalam bahasa Indonesia menjadi Diagram Alir Data (DAD) adalah refresentasi grafik yang 
menggambarkan aliran informasi dan transformasi informasi yang di aplikasikan sebagai data yang mengatur dari masukan (input) dan keluaran(output). DFD tidak sesuai untuk memodelkan sistem yang menggunakan pemograman berorientasi objek."

\subsection{Sistem Informasi}

Karya ilmiah yang dibuat oleh Jogiyanto H.M. (2013:34), menerangkan bahwa Sistem (System) dapat didefinisikan dengan pendekatan prosedur dan dengan pendekatan komponen. Dengan pendekatan prosedur, sistem dapat didefinisikan sebagai kumpulan dari prosedurprosedur yang mempunyai tujuan tertentu. Dengan pendekatan komponen, sistem dapat didefinisikan sebagai kumpulan dari komponen yang saling berhubungan satu dengan yang lainnya membentuk satu kesatuan untuk mencapai tujuan tertentu.

Sedangkan Menurut Gordon B. Davis dalam Hartono (2013:15), berbendapat bahwa "information is data has beenprocessed into a form that is meaningful to the recipient and is of real or preceived value incurrent or prospective decision." (Informasi adalah data yang telah diolah menjadi suatu bentukyang berguna bagi penerimanya dan memiliki nilai bagi pengambilan keputusan saat ini atau dimasa yang akan datang).

\subsection{Metode Least Square}

Assauri, Sofyan (1991) Berpendapat bahwa metode Least Square merupakan salah satu metode berupa data deret berkala atau time series, yang mana dibutuhkan data-data penjualan dimasa lampau untuk melakukan peramalan penjualan dimasa mendatang sehingga dapat ditentukan hasilnya. Least Square adalah metode peramalan yang digunakan untuk melihat trend dari data deret waktu.

Metode Least Square dibagi menjadi dua yaitu, jika data berjumlah ganjil maka jarak antara dua waktu diberi 1 satuan, jika data berjumlah genap maka jarak antara dua waktu diberi nilai 2 satuan, yang dimana jika diatas 0 maka diberi tanda negative dan dibawah 0 diberi tanda positif. Persamaan 2 merupakan persamaan metode Least Square.

$Y^{\prime}=a+b X$

$a=\frac{\sum Y}{N}$

$b=\frac{\sum X Y}{\sum X^{2}}$

Dimana :

$\mathrm{N}=$ jumlah data

$\mathrm{X}=$ variabel bebas

$\mathrm{Y}^{\prime}=$ variabel terikat

$\mathrm{a}=$ nilai konstanta $\mathrm{b}=$ koefisien arah regresi

\subsection{Uji Keakurasian Metode Least Square}

Keakurasian suatu forecasting ditentukan dari besarnya kesalahan yang terjadi antara data forecast dengan data aktual. Besarnya kesalahan dapat disebabkan oleh faktor yang tidak diduga. Adapun cara untuk menghitung besarnya kesalahan yaitu:

a. Mean Square Error (MSE), merupakan rataan selisih dua kuadarat antara nilai yang diprediksikan dengan yang diamati

b. Root Mean Square Error (RMSE), merupakan akar dari MSE

c. Mean Absolute Percentage Erorr (MAPE), merupakan rataan difernsi absolut antara nilai yang diprediksi dan yang sebenarnya.

Rumus dari ketiga pengujian keakurasian dapat dinyatakan sebagai berikut:

$\mathrm{MSE}=\sum \frac{\left(\mathrm{Y}^{\mathrm{t}}-\hat{\hat{p}}\right)^{2}}{n}$ Persamaan 2.4

RMSE $=\sqrt{\sum \frac{\left(\gamma^{\mathrm{t}}-\hat{\gamma}\right)^{2}}{n}}$ Persamaan 2.5

MAPE $=\frac{1}{n} \sum_{t=1}^{n} \frac{|\gamma t-\hat{Y} t|}{\gamma t} \times 100 \%$ Persamaan 2.6

Dimana:

$Y t=$ Nilai aktual pada periode $\mathrm{t}$

$\hat{\mathrm{Y}}_{t}=$ Nilai prediksi pada periode $\mathrm{t}$ $n=$ Jumlah data

\section{METODE PENELITIAN}

Adapun Penelitian ini akan membahas mengenai sistem informasi kebutuhan bahan pembangunan rumah berbasis website.

\subsection{Analisa kebutuhan Fungsional}

Dalam pembuatan sistem informasi, terdapat beberapa kebutuhan fungsional antara lain:

Tabel 1. Kebutuhan Fungsional

\begin{tabular}{|c|l|}
\hline No & \multicolumn{1}{|c|}{ Fungsional } \\
\hline 1 & Sistem dapat melakukan validasi login. \\
\hline 2 & $\begin{array}{l}\text { Sistem dapat melakukan input data penjualan } \\
\text { tanah kavling. }\end{array}$ \\
\hline 3 & $\begin{array}{l}\text { Sistem dapat melakukan input data penjualan } \\
\text { rumah. }\end{array}$ \\
\hline 4 & $\begin{array}{l}\text { Sistem dapat melakukan input data bahan baku } \\
\text { pembangunan rumah. }\end{array}$ \\
\hline 5 & $\begin{array}{l}\text { Sistem dapat melakukan prediksi penjualan tanah } \\
\text { kavling untuk tahun berikutnya didalam website } \\
\text { menggunakan metode least square. }\end{array}$ \\
\hline 6 & $\begin{array}{l}\text { Sistem dapat melakukan prediksi penjualan } \\
\text { rumah untuk tahun berikutnya didalam website } \\
\text { menggunakan metode least square. }\end{array}$ \\
\hline 7 & $\begin{array}{l}\text { Sistem dapat melakukan prediksi kebutuhan } \\
\text { bahan pembangunan rumah untuk tahun } \\
\text { berikutnya didalam website menggunakan } \\
\text { metode least square. }\end{array}$ \\
\hline 8 & $\begin{array}{l}\text { Sistem dapat menampilkan laporan data forecast } \\
\text { penjualan rumah, penjualan tanah dan bahan. }\end{array}$ \\
\hline
\end{tabular}


Berdasarkan tabel 1 terlihat bahwa semua proses yang digunakan pada banyak fitur pada website berhasil dijalankan, hal ini dibuktikan oleh fitur yang ada pada proses sistem informasi dapat diakses sebagaimana fungsi semestinya.

\subsection{Flowchart Sistem}

Flowchart Sistem menunjukkan alur kerja atau proses urutan sistem dari awal berjalanya sistem hingga berakhir, alur ini hanya menggambarkan langkah-langkah umum dari awal mula hingga akhir proses. Berikut gambaran Flowchart sistem seperti yang ditunjukan pada gambar 1.

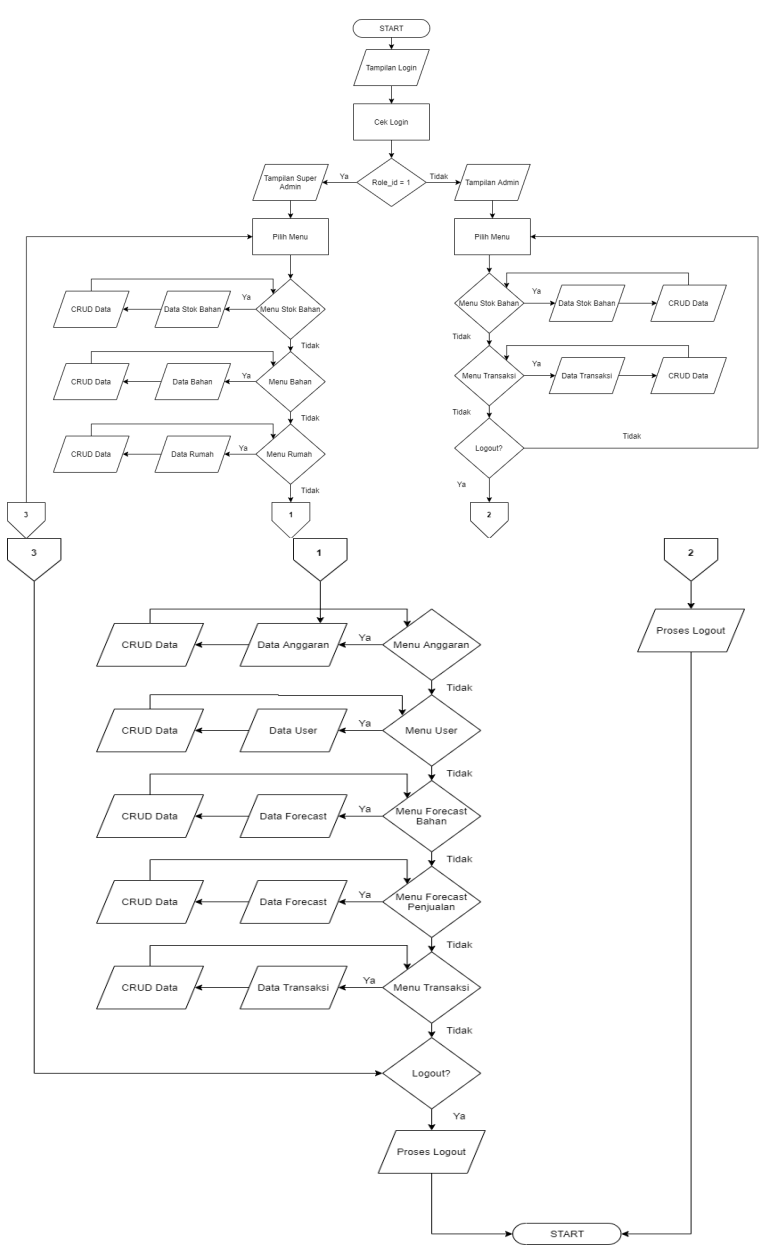

Gambar 1. Flowchart Sistem

Seperti pada flowchart di atas, proses pertama adalah login pada halaman login, jika login tidak berhasil maka akan tetap dihalaman tersebut jika login berhasil maka akan masuk ke halaman selanjutnya tergantung dari roll id nya. Selanjutnya admin dapat memasukkan data bahan serta data transaksi, super admin bisa mengakses semua fitur yang ada termasuk mencetak laporan.

\subsection{Flowchart Metode}

Pada Flowchart Metode, akan menjelaskan tentang alur cara kerja pengolahan data predikai mulai data diinputkan sampai dengan proses peramalan melalui website. Berikut merupakan gambar dari flowchart metode yang akan dibuat pada gambar 2

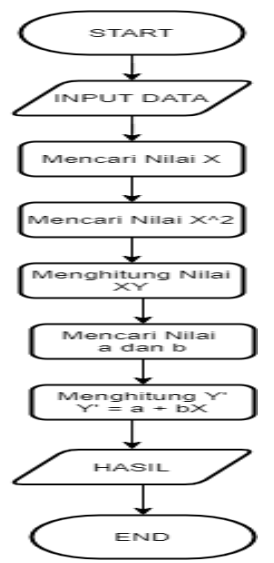

Gambar 2. Flowchart Metode

Seperti pada gambar flowchart diatas pertama tama adalah menginputkan data bahan dan penjualan rumah sesuai dengan data penjualan yang terdahulu setelah data diinputkan makan akan masuk pada tahap pencarian niali $\mathrm{x}$, setelah nilai didapatkan maka akan mencari nilai dari $\mathrm{x}^{\wedge} 2$. Setelah nilai didapatkan langkah selanjutnya yaitu mencari nilai xy dengan mengkalikan nilai x dan y. Untuk menuju mencari nilai y' dilakukan operasi penjumlahan nilai $\mathrm{a}+\mathrm{bX}$ sehingga menghasilkan data peamalan untuk periode tahun selanjutnya.

\subsection{Data Flow Diagram 0}

Data Flow Diagram (DFD) adalah diagram yang menggunakan notasinotasi untuk menggambarkan arus dari sistem. DFD sering digunakan untuk menggambarkan arus dari sistem yang telah ada atau sistem yang baru yang akan dikembangkan secara logika tanpa mempertimbangkan lingkungan fisik dimana data tersebut mengalir. Berikut merupakan gambar dari data flow diagram 0 yang akan dibuat pada gambar 3

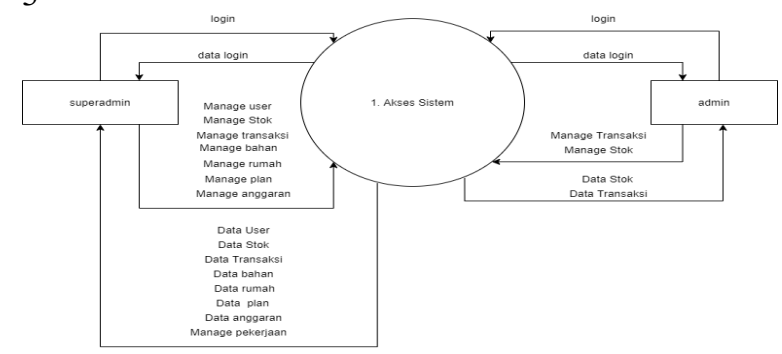

Gambar 3. Data Flow Diagram 0 


\subsection{Data Flow Diagram 1}

DFD level 1 merupakan perspesifikasian proses dari level 0, dalam level ini proses akan dipecah menjadi lebih rinci. Berikut merupakan gambar dari data flow diagram 1 yang akan dibuat pada gambar 4

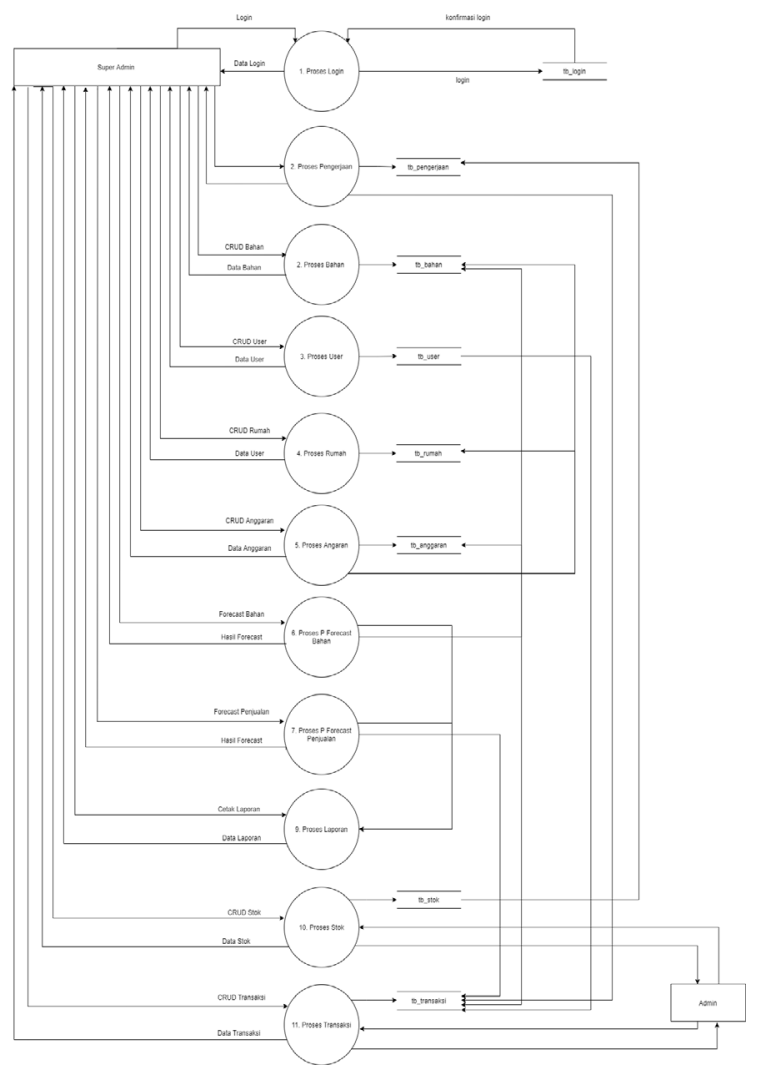

Gambar 4. Data Flow Diagram 1

\section{HASIL DAN PEMBAHASAN}

\subsection{Tampilan Halaman Login}

Pada halaman login user harus memasukkan username dan password untuk dapat mengakses fitur yang ada. Berikut merupakan gambar dari Tampilan Login yang akan dibuat pada gambar 5

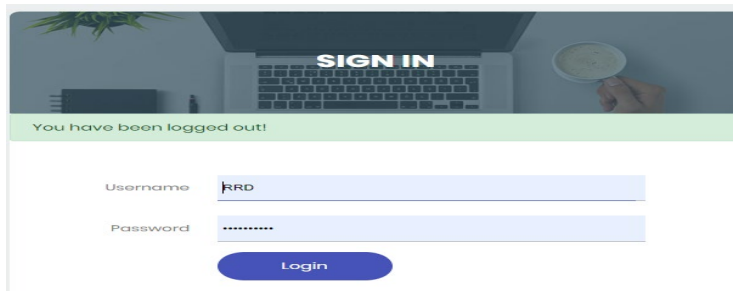

Gambar 5. Tampilan Halaman Admin

\subsection{Halaman Dashboard Super Admin}

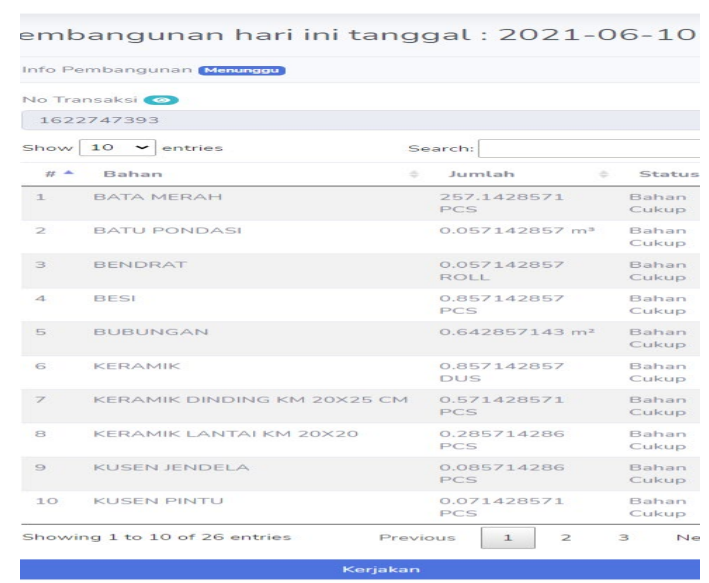

Gambar 6. Tampilan Halaman Transaksi Admin

\subsection{Tampilan Halaman Stok Bahan Super Admin}

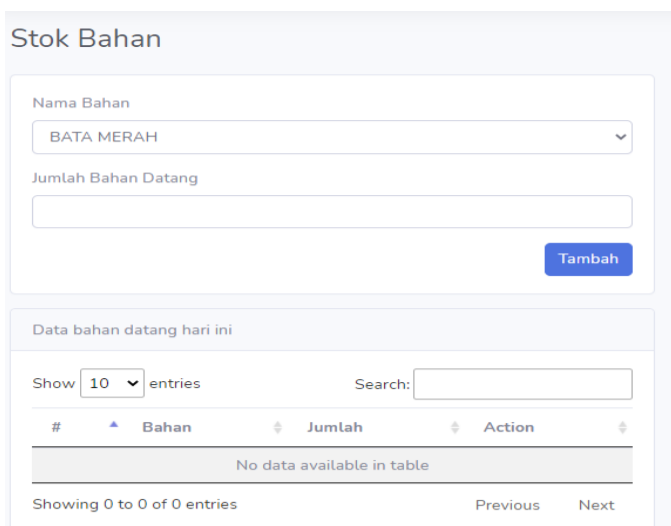

Gambar 7. Halaman Stok Bahan Super Admin

4.4. Tampilan Halaman Data Bahan Super Admin

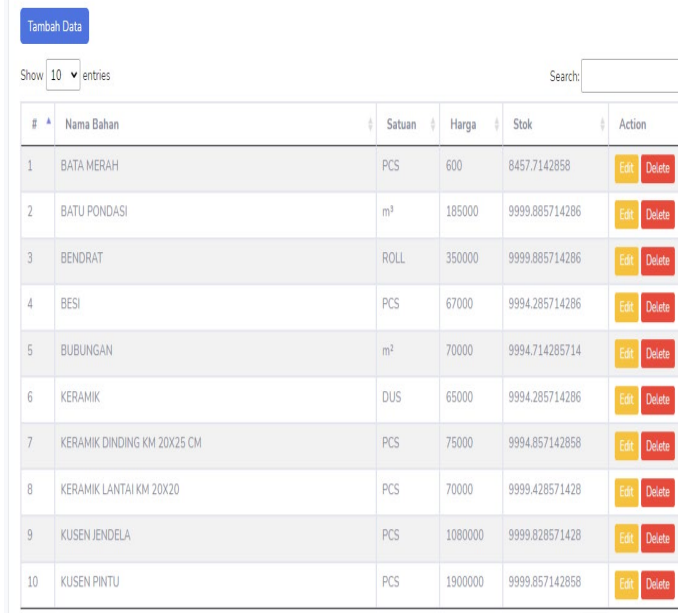

Gambar 8. Halaman Data Bahan Super Admin 


\subsection{Tampilan Halaman Data Rumah Super Admin}

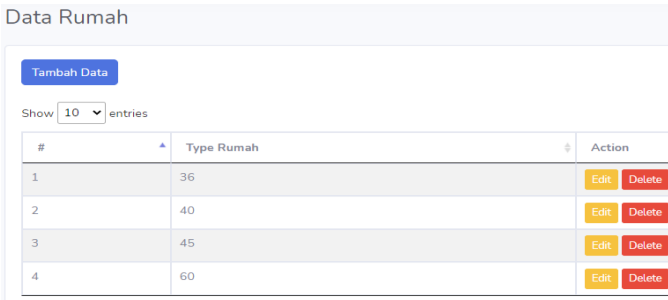

Gambar 9. Halaman Data Rumah Super Admin

\subsection{Tampilan Halaman Data Anggaran Super Admin}

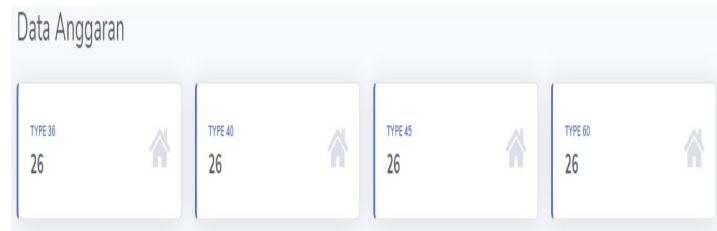

Gambar 10. Halaman Data Anggaran Super Admin

\subsection{Tampilan Halaman Forecast Bahan Super Admin}

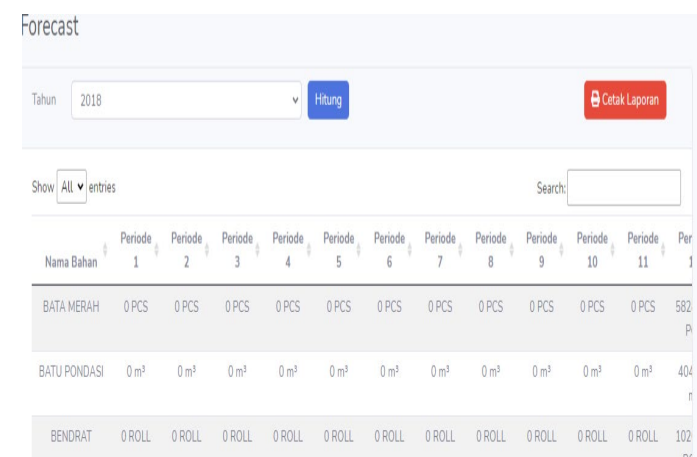

Gambar 11. Halaman Forecast Bahan Super Admin

\subsection{Tampilan Forecast Penjualan Super Admin}

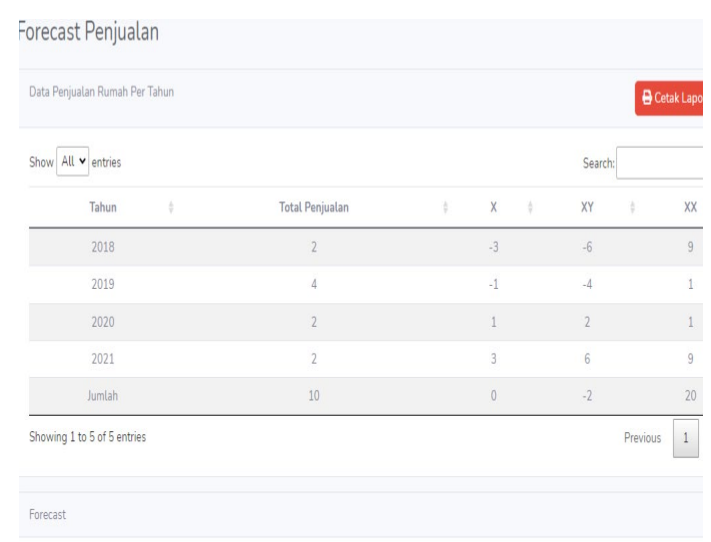

Gambar 12. Halaman Forecast Penjualan Super Admin

\subsection{Tampilan Halaman Transaksi Super Admin}

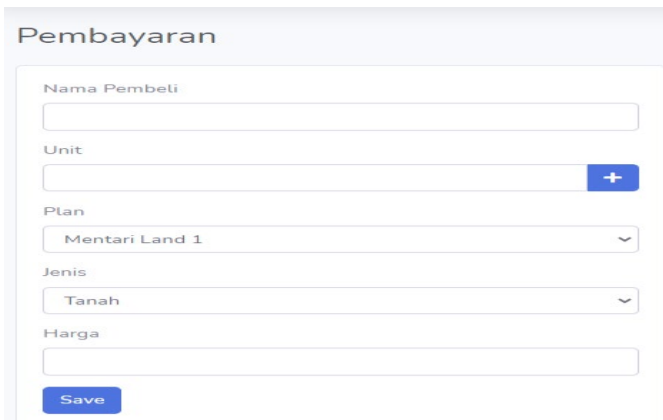

Gambar 13. Halaman Transaksi Super Admin

\subsection{Pengujian Fungsionalitas Sistem}

Pada pengujian Fungsionalitas sistem akan dilakukan percobaan untuk menguji semua fungsi yang yang ada pada sistem apakah bekerja dengan normal atau tidak. Pengujian dilakukan pada 3 browser pada perangkat dengan spesifikasi CPU yang digunakan adalah Intel Core I5 generasi 7 Quad Core Up to $2.4 \mathrm{Ghz}$, RAM 6 GB.

\subsection{Pengujian Fungsionalitas Sistem Admin}

Hasil dari pengujian fungsionalitas sistem dapat ditujukkan pada Tabel 2.

Tabel 2. Pengujian Fungsionalitas Sistem Admin

\begin{tabular}{|l|c|c|c|}
\hline \multirow{2}{*}{ Fungsi } & \multicolumn{3}{|c|}{ Browser } \\
\cline { 2 - 4 } & $\begin{array}{c}\text { Microsoft } \\
\text { Edge }\end{array}$ & $\begin{array}{c}\text { Google } \\
\text { Chrome }\end{array}$ & $\begin{array}{c}\text { Mozilla } \\
\text { Firefox }\end{array}$ \\
\hline Login & $\sqrt{ }$ & $\sqrt{ }$ & $\sqrt{ }$ \\
\hline Halaman Admin & $\sqrt{ }$ & $\sqrt{ }$ & $\sqrt{ }$ \\
\hline $\begin{array}{l}\text { Halaman Stok Bahan } \\
\text { Admin }\end{array}$ & $\sqrt{ }$ & $\sqrt{ }$ & $\sqrt{ }$ \\
\hline $\begin{array}{l}\text { Input Data Stok Bahan } \\
\text { Admin }\end{array}$ & $\sqrt{ }$ & $\sqrt{ }$ & $\sqrt{ }$ \\
\hline $\begin{array}{l}\text { Ubah Data Stok Bahan } \\
\text { Admin }\end{array}$ & $\sqrt{ }$ & $\sqrt{ }$ & $\sqrt{ }$ \\
\hline $\begin{array}{l}\text { Hapus Data Stok Bahan } \\
\text { Admin }\end{array}$ & $\sqrt{ }$ & $\sqrt{ }$ & $\sqrt{ }$ \\
\hline $\begin{array}{l}\text { Halaman Pembayaran } \\
\text { Admin }\end{array}$ & $\sqrt{ }$ & $\sqrt{ }$ & $\sqrt{ }$ \\
\hline $\begin{array}{l}\text { Input Data Pembayaran } \\
\text { Admin }\end{array}$ & $\sqrt{ }$ & $\sqrt{ }$ & $\sqrt{ }$ \\
\hline $\begin{array}{l}\text { Ubah Data Pembayaran } \\
\text { Admin }\end{array}$ & $\sqrt{ }$ & $\sqrt{ }$ & $\sqrt{ }$ \\
\hline $\begin{array}{l}\text { Hapus Data Pembayaran } \\
\text { Admin }\end{array}$ & $\sqrt{ }$ & $\sqrt{ }$ \\
\hline Halaman Dashboard Admin & $\sqrt{ }$ & \\
\hline
\end{tabular}

Berdasarkan tabel 2 dapat disimpulkan bahwa pengujian funsgsionalitas sistem admin pada berbagai webbrowser yaitu:

1. MicrosoftEdge versi 91.0.864.67

2. GoogleChrome versi 91.0.4472.124

3. Mozillafirefox versi 89.0.1

Berhasil menjalankan semua fitur dan dapat menjalankan hak akses yang ditentukan dengan adanya tanda:

$\sqrt{ }$ : yang berarti berhasil dan tanda $\mathrm{x}$ : yang berarti gagal. 


\subsection{Pengujian Fungsionalitas Sistem Super Admin}

Tabel 3. Pengujian Fungsionalitas Sistem Super

\begin{tabular}{|c|c|c|c|}
\hline \multicolumn{4}{|c|}{ Admin } \\
\hline \multirow[b]{2}{*}{ Fungsi } & \multicolumn{3}{|c|}{ Browser } \\
\hline & $\begin{array}{l}\text { Microsoft } \\
\text { Edge }\end{array}$ & $\begin{array}{l}\text { Google } \\
\text { Chrome }\end{array}$ & $\begin{array}{l}\text { Mozilla } \\
\text { Firefox }\end{array}$ \\
\hline Login & $\sqrt{ }$ & $\sqrt{ }$ & $\sqrt{ }$ \\
\hline Halaman Super Admin & $\sqrt{ }$ & $\sqrt{ }$ & $\sqrt{ }$ \\
\hline $\begin{array}{l}\text { Halaman Stok Bahan } \\
\text { Super Admin }\end{array}$ & $\sqrt{ }$ & $\sqrt{ }$ & $\sqrt{ }$ \\
\hline $\begin{array}{l}\text { Input Data Stok Bahan } \\
\text { Super Admin }\end{array}$ & $\sqrt{ }$ & $\sqrt{ }$ & $\sqrt{ }$ \\
\hline $\begin{array}{l}\text { Ubah Data Stok Bahan } \\
\text { Super Admin }\end{array}$ & $\sqrt{ }$ & $\sqrt{ }$ & $\sqrt{ }$ \\
\hline $\begin{array}{l}\text { Hapus Data Stok Bahan } \\
\text { Super Admin }\end{array}$ & $\sqrt{ }$ & $\sqrt{ }$ & $\sqrt{ }$ \\
\hline $\begin{array}{l}\text { Halaman Pembayaran } \\
\text { Super Admin }\end{array}$ & $\sqrt{ }$ & $\sqrt{ }$ & $\sqrt{ }$ \\
\hline $\begin{array}{l}\text { Input Data Pembayaran } \\
\text { Super Admin }\end{array}$ & $\sqrt{ }$ & $\sqrt{ }$ & $\sqrt{ }$ \\
\hline $\begin{array}{l}\text { Ubah Data Pembayaran } \\
\text { Super Admin }\end{array}$ & $\sqrt{ }$ & $\sqrt{ }$ & $\sqrt{ }$ \\
\hline $\begin{array}{l}\text { Hapus Data Pembayaran } \\
\text { Super Admin }\end{array}$ & $\sqrt{ }$ & $\sqrt{ }$ & $\sqrt{ }$ \\
\hline $\begin{array}{l}\text { Halaman Data Bahan } \\
\text { Super Admin }\end{array}$ & $\sqrt{ }$ & $\sqrt{ }$ & $\sqrt{ }$ \\
\hline $\begin{array}{l}\text { Input Data Bahan Super } \\
\text { Admin }\end{array}$ & $\sqrt{ }$ & $\sqrt{ }$ & $\sqrt{ }$ \\
\hline $\begin{array}{l}\text { Ubah Data Bahan Super } \\
\text { Admin }\end{array}$ & $\sqrt{ }$ & $\sqrt{ }$ & $\sqrt{ }$ \\
\hline $\begin{array}{l}\text { Hapus Data Bahan Super } \\
\text { Admin }\end{array}$ & $\sqrt{ }$ & $\sqrt{ }$ & $\sqrt{ }$ \\
\hline $\begin{array}{l}\text { Halaman Data Rumah } \\
\text { Super Admin }\end{array}$ & $\sqrt{ }$ & $\sqrt{ }$ & $\sqrt{ }$ \\
\hline $\begin{array}{l}\text { Input Data Rumah Super } \\
\text { Admin }\end{array}$ & $\sqrt{ }$ & $\sqrt{ }$ & $\sqrt{ }$ \\
\hline $\begin{array}{l}\text { Ubah Data Rumah Super } \\
\text { Admin }\end{array}$ & $\sqrt{ }$ & $\sqrt{ }$ & $\sqrt{ }$ \\
\hline $\begin{array}{l}\text { Hapus Data Rumah } \\
\text { Super Admin }\end{array}$ & $\sqrt{ }$ & $\sqrt{ }$ & $\sqrt{ }$ \\
\hline $\begin{array}{l}\text { Halaman Data Anggaran } \\
\text { Super Admin }\end{array}$ & $\sqrt{ }$ & $\sqrt{ }$ & $\sqrt{ }$ \\
\hline $\begin{array}{l}\text { Input Data Anggaran } \\
\text { Super Admin } \\
\end{array}$ & $\sqrt{ }$ & $\sqrt{ }$ & $\sqrt{ }$ \\
\hline $\begin{array}{l}\text { Ubah Data Anggaran } \\
\text { Super Admin }\end{array}$ & $\sqrt{ }$ & $\sqrt{ }$ & $\sqrt{ }$ \\
\hline $\begin{array}{l}\text { Hapus Data Anggaran } \\
\text { Super Admin }\end{array}$ & $\sqrt{ }$ & $\sqrt{ }$ & $\sqrt{ }$ \\
\hline $\begin{array}{l}\text { Halaman Data User } \\
\text { Super Admin }\end{array}$ & $\sqrt{ }$ & $\sqrt{ }$ & $\sqrt{ }$ \\
\hline $\begin{array}{l}\text { Input Data User Super } \\
\text { Admin }\end{array}$ & $\sqrt{ }$ & $\sqrt{ }$ & $\sqrt{ }$ \\
\hline $\begin{array}{l}\text { Ubah Data User Super } \\
\text { Admin }\end{array}$ & $\sqrt{ }$ & $\sqrt{ }$ & $\sqrt{ }$ \\
\hline $\begin{array}{l}\text { Hapus Data User Super } \\
\text { Admin }\end{array}$ & $\sqrt{ }$ & $\sqrt{ }$ & $\sqrt{ }$ \\
\hline Halaman Forecast Bahan & $\sqrt{ }$ & $\sqrt{ }$ & $\sqrt{ }$ \\
\hline Proses Forecast Bahan & $\sqrt{ }$ & $\sqrt{ }$ & $\sqrt{ }$ \\
\hline $\begin{array}{l}\text { Cetak Hasil Forecast } \\
\text { Bahan }\end{array}$ & $\sqrt{ }$ & $\sqrt{ }$ & $\sqrt{ }$ \\
\hline $\begin{array}{l}\text { Halaman Forecast } \\
\text { Penjualan }\end{array}$ & $\sqrt{ }$ & $\sqrt{ }$ & $\sqrt{ }$ \\
\hline Proses Forecast Penjualan & $\sqrt{ }$ & $\sqrt{ }$ & $\sqrt{ }$ \\
\hline $\begin{array}{l}\text { Cetak Hasil Forecast } \\
\text { Penjualan }\end{array}$ & $\sqrt{ }$ & $\sqrt{ }$ & $\sqrt{ }$ \\
\hline $\begin{array}{l}\text { Halaman Dashboard } \\
\text { Super Admin }\end{array}$ & $\sqrt{ }$ & $\sqrt{ }$ & $\sqrt{ }$ \\
\hline
\end{tabular}

Berdasarkan tabel 3 dapat disimpulkan bahwa pengujian funsgsionalitas sistem superadmin pada berbagai webbrowser yaitu:

1. MicrosoftEdge versi 91.0.864.67

2. GoogleChrome versi 91.0.4472.124

3. Mozillafirefox versi 89.0.1

Berhasil menjalankan semua fitur dan dapat menjalankan hak akses yang dinuktikan dengan adanya tanda:

$\sqrt{ }$ : yang berarti berhasil dan tanda $\mathrm{x}$ : yang berarti gagal.

\subsection{Uji Keakurasian Least Square.}

Setelah melakukan Forecasting terhadap penjualan Rumah pada PT. Taniya Multi Properti, uji keakurasian dilakukan untuk mencari tingkat akurasi dari hasil perhitungan forecasting penjualan Rumah menggunakan metode MAPE. Pegujian keakurasian menggunakan MAPE dapat dikategorikan baik apabila nilai presentasi kurang dari $20 \%$, dapat di kategorikan wajar apabila nilai presentasi kurang dari $50 \%$, dan dapat di kategorikan kurang baik apabila nilai presentasi leboh dai 50\%. Semakin kecil penyimpangan antara data aktual dan data prediksi maka metode prediksi yang digunakan baik.

\subsection{Uji Keakurasian Forecast Penjualan}

Pengujian keakurasian forecasting penjualan untuk menentukan nilai error pada sistem yang di buat terdapat pada tabel berikut yang merupakan data pencarian nilai error untuk forecast penjualan rumah serta bahan bata merah.

Tabel 4. Pengujian Keakurasian Forecast penjualan

\begin{tabular}{|c|c|c|c|c|c|}
\hline $\begin{array}{c}\text { indek } \\
\text { waktu }\end{array}$ & aktual & $\begin{array}{c}\text { Per } \\
\text { amalan }\end{array}$ & error & $\begin{array}{c}\text { absolut } \\
\text { error }\end{array}$ & $\begin{array}{c}\text { absolut } \\
\text { error/ } \\
\text { aktual }\end{array}$ \\
\hline $\mathrm{t}$ & at & $\mathrm{ft}$ & at-ft & $\mid$ at-ft $\mid$ & $\mid$ (at-ft)/ft $\mid$ \\
\hline 2019 & 7 & 2 & -5 & 5 & 0,71 \\
\hline 2020 & 4 & 12 & -8 & 8 & 2 \\
\hline 2021 & 2 & 12 & -10 & 10 & 5 \\
\hline$\sum$ & 13 & 26 & -23 & 23 & 7,71 \\
\hline \multicolumn{7}{|c|}{ MAPE } & 3 \\
\hline \multicolumn{7}{|c|}{} \\
\hline
\end{tabular}

Pada tabel 4 di dapat bahwa pengujian keakurasian sistem forecasting dapat di kategorikan baik karena persentase error hasil perhitungan $M A P E$ di bawah $20 \%$.

\subsection{Uji Keakurasian Forecast Bahan}

Pengujian keakurasian forecasting bahan untuk menentukan nilai error pada sistem yang di buat terdapat pada tabel berikut yang merupakan data pencarian nilai error untuk forecast bahan bata merah. 
Tabel 5. Pengujian Keakurasian Forecast bahan

\begin{tabular}{|c|c|c|c|c|c|}
\hline indek waktu & aktual & peramalan & error & absolut error & absolut error/aktual \\
\hline t & at & $\mathrm{ft}$ & at-ft & |at-ft| & $|(a t-f t) / f t|$ \\
\hline 2019 & 103.714 & 350.264 & -246.550 & 246.550 & 2,38 \\
\hline 2020 & 486.857 & 544.760 & -57.903 & 57.903 & 0,12 \\
\hline 2021 & 352.971 & 540.724 & -187.753 & 187.753 & 0,53 \\
\hline$\Sigma$ & & 1435748 & $-1,435.748$ & 1.435 .748 & 3,03 \\
\hline \multicolumn{5}{|c|}{$n$} & 3 \\
\hline \multicolumn{5}{|c|}{ MAPE } & $1.01 \%$ \\
\hline
\end{tabular}

Pada tabel 5 di dapat bahwa pengujian keakurasian sistem forecasting dapat di kategorikan baik karena persentase error hasil perhitungan $M A P E$ di bawah $20 \%$.

\section{KESIMPULAN DAN SARAN}

\subsection{Kesimpulan}

Adapun kesimpulan yang dapat penulis uraikan setelah melakukan perancangan sistem informasi kebutuhan bahan pembangunan rumah berbasis website antara lain yaitu:

1. Pengujian fungsionalitas manajemen bahan baku pembangunan rumah pada aplikasi dinyatakan sukses ketika muncul peringatan kekurangan bahan pada tabel status pekerjaan harian.

2. Hasil uji perhitungan metode menggunakan data penjualan Rumah PT. Taniya Multi Properti tahun 2019 sebanyak 12 unit. Namun pada data aktual memperoleh data sebanyak 4 unit. Oleh karena itu di buat perhitungan nilai error dengan menggunakan metode MAPE dan memperoleh hasil persentase error sebesar 25\% yang berarti wajar.

3. Hasil uji keakurasian untuk penjualan rumah dengan menggunakan data penjualan rumah pada periode selanjutnya (2021) menghasilkan data forecast sebesar 0 unit, sedangkan data aktual penjualan 2021 sebesar 3 unit. Oleh karena itu di buat perhitungan nilai error dengan menggunakan metode MAPE dan memperoleh hasil persentase error sebesar $16,667 \%$ yang berarti baik.

\subsection{Saran}

Penelitian yang telah dilakukan memiliki banyak kekurangan, maka dari itu terdapat saran yang di kemukakan untuk mengembangkan sistem kedepannya yaitu:
1. Untuk mengembangkan aplikasi supaya lebih sempurna, baik nya untuk data yang di gunakan merupakan data penjualan lebih dari 8 tahun.

2. Pengembangan aplikasi akan lebih sempurna apabila ditambahkan metode regresi liniear untuk mengolah dan meramalkan penjualan tahun dan periode selanjutnya.

\section{DAFTAR PUSTAKA}

[1] Assauri, Sofyan., Teknik dan Metode Peramalan. LPFE UI, Jakarta, 1991.

[2] Bangun Unedo Putra Manurung. (2015). Implementasi Least Square Dalam Untuk Prediksi Penjualan Sepeda Motor PT Graha Auto Pratama. Jurnal Riset Komputer (JURIKOM), 2(6), 21-24.

[3] Brady dan Loonam J.2010. Exploring the use of entity-relationship diagramming as a technique to support grounded theory inquiry. Qualitative Research in Organization and Management.

[4] Hakim, Lukmanul. 2004. Cara Cerdas Menguasai Layout, Desain dan Aplikasi Web. PT Elex Media Komputindo Jakarta.

[5] Josef Bernadi. (2013). Aplikasi Sistem Informasi Penjualan Berbasis Web.

[6] Muhamad Ightana Hakim (2019). Sistem Informasi Penerbitan Akta Cerai Di Pengadilan Agama Lumajang. JATI (Jurnal Mahasiswa Teknik Informatika), 3(2), 75-82.

[7] Rasjid, Fajar Efendi. $2014 . \quad$ Bahasa Pemrograman Populer PHP. https://www.ubaya.ac.id/2018/content/articles _detail/144/Bahasa-Pemrograman-populerPHP.html.

[8] Ratningsih. (2017). Forecasting Penjualan Rumah Dengan Menggunakan Metode Trend Moment pada PT. Ruma Kita Prima Rasa. Jurnal Perspektif, XV (1) , 40-48.

[9] Sukamto, Rosa A. dan M. Salahuddin. 2014. Rekayasa Perangkat Lunak Terstruktur dan Berorientasi Objek. Bandung: Informatika.

[10] Wibawanto, W (2017). Desain dan Pemrograman Multimedia Pembelajaran Interaktif. Jember: Cerdas Ulet Kreatif.

[11] Yenni Indri Damayanti (2017). Pengembangan Sistem Informasi Akademik Berbasis Androidstudi Kasus Teknik Informatika Itn Malang. JATI (Jurnal Mahasiswa Teknik Informatika), 1(1), 17-22 